\title{
Prevalence of Iron Deficiency Anaemia among Pregnant Women in Calabar, Cross River State Nigeria
}

\author{
${ }^{1}$ Okafor, Ifeyinwa M., ${ }^{1}$ Asemota, Enosakhare A., ${ }^{2}$ Antai, A. B., \\ ${ }^{1}$ Usanga, Essien A. \\ ${ }^{I}$ Department of Medical Lab. Science, Haematology Unit, University of Calabar,Calabar Nigeria. \\ ${ }^{2}$ Department of physiology, faculty of basic medical sciences, University of Calabar,Calabar Nigeria.
}

\begin{abstract}
Iron is a component of a number of proteins including haemoglobin, myoglobin, cytochromes and enzymes involved in redox reactions. Inadequate iron intake can lead to varying degrees of deficiency, from low iron stores to early iron deficiency and iron-deficiency anaemia and this is dangerous to both baby and mother. The objective of this study is to assess the prevalence of iron deficiency and iron deficiency anaemia among pregnant women in Calabar, Cross River State Nigeria. Seventy pregnant women within the age range of 1545 years from University of Calabar Teaching Hospital were recruited as subjects in this study. The control consisted of fifty age-matched apparently healthy non-pregnant women. The tests that were carried out using standard method include include full blood count (packed cell volume, haemoglobin, mean cell haemoglobin, mean cell haemoglobin concentration and red cell count), serum iron, total iron binding capacity, transferrin saturation,serum ferritin and soluble transferrin recptor. The prevalence of anaemia and iron deficiency anaemia were found to be significantly higher $(p<0.05)$ among pregnant women $(20.0 \%, 15.7 \%)$ when compared to non-pregnant women. The mean haemoglobin, haematocrit, serum iron, serum ferritin and transferrin saturation were significantly reduced $(p<0.01)$ in pregnant than non-pregnant women while total iron binding capacity and soluble transferrin receptor significantly $(p<0.01)$ increased in pregnant than nonpregnant. It was also shown that pregnant women in their third trimesters and multigravidae had the highest prevalence of iron deficiency and iron deficiency anaemia while pregnant women in their second trimester had the highest prevalence of anaemia. In conclusion the study has shown that the prevalence of anaemia, iron deficiency and iron deficiency anaemia among pregnant women in the studied area were still high and can be considered public health problem.

Key words: Anaemia, Iron deficiency, Soluble transferrin receptor
\end{abstract}

\section{Introduction}

Iron is a universal co-factor for mitochondrial energy generation and supports the growth and differentiation of all cell types. During pregnancy there is a significant increase in the amount of iron required to increase the red cell mass, expand the plasma volume and to allow for the growth of the fetal-placental unit and this impose such a demand on maternal iron stores that iron supplementation at daily doses between 18 and 100 mg from 16 weeks gestation onwards could not completely prevent the depletion of maternal iron stores at term $^{1}$. The development of iron deficiency anaemia is associated with increased risk of preterm births and low birth-weight infants ${ }^{2}$. The physiologic importance of storage iron is that it provides a rapidly available supply in the event of blood loss ${ }^{3}$. To achieve iron balance, towards the end of pregnancy, the absorption of 4-5 mg/day is necessary. Requirements are higher during periods of rapid growth in early childhood and adolescence ${ }^{4}$.

Anaemia is a global public health problem affecting both developing and developed countries with major consequences for human health as well as social and economic development. It occurs at all stages of the life cycle, but is more prevalent in pregnant women and young children. In 2002, iron deficiency anaemia (IDA) was considered to be among the most important contributing factors to global disease burden ${ }^{5}$. Inadequate iron intake can lead to varying degrees of deficiency such as low iron stores, early iron deficiency and irondeficiency anaemia ${ }^{6}$. Whole grain cereals, meats, fish and poultry are the major contributors to iron intake, but the iron from plant sources is less bio-available. The form in which iron is consumed will affect dietary intake requirements as not all dietary iron is equally available to the body. The factors that determine the proportion of iron absorbed from food are complex. They include the iron status of an individual, as well as the iron content and composition of a meal. Iron deficiency anaemia (IDA) is a problem of public health significance in Nigeria and this study surveys the prevalence of iron deficiency and iron deficiency anaemia among pregnant women in Calabar, Cross River State, Nigeria 


\section{Materials and method}

This study was conducted in Calabar. The study subjects were pregnant women who came to book their pregnancy at antenatal clinic of University of Calabar Teaching Hospital Calabar, Cross River State.

Seventy pregnant women within the age range of 15-45 years were used as subjects in this study. The control subjects consisted of fifty age-matched apparently healthy non-pregnant women from Calabar Metropolis. The subjects were given questionnaires to fill which provided useful information for this study.Full blood count was carried out using full automatic blood cell counter, PCE-210 version 5.10 by ERMA INC. Tokyo . Serum iron(SI) and total iron binding capacity (TIBC) were determined using serum iron kit by TECO DIAGNOSTICS 1268 N. Lakeview Avenue Anaheim, CA 92807. Transferrin saturation (TS) was determined using this formular- $\mathrm{TS}=$
serum Iron concentration
$\mathrm{x} 100$

TIBC

Serum ferritin( $\mathrm{Sf}$ ) was determined using human ferritin enzyme immunoassay test kit by Diagnostic Automation, Inc. Calabasas USA. Soluble transferrin receptor (STfR) was measured using human soluble transferrin receptor ELISA Kit by Biovendor Diagnostics USA. The manufacturer instruction was obeyed when using all the kits

All statistical analyses were performed by using the program Statistical Package for Social Sciences (SPSS ) for windows version 16.0, SPSS Inc., Chicago, US

\section{Result}

Demographic characteristics of the study groups is presented in table 1. The result shows that $38(54.29 \%)$ of pregnant women were house wives and the rest were mostly students or teachers while $19(38.00 \%)$ of non-pregnant women were house wives and 31(62.0\%) teachers/students. Twenty three (32.90\%) and $42(60.00 \%)$ of the study groups were holding secondary or university degree respectively while $28(56.0 \%)$ of the non-pregnant women had tertiary education. Fifty seven $(81.40 \%)$ of the pregnant women involved in this study were taking haematenics. The mean haemoglobin (11.03 \pm 0.13$)$, haematocrit $(0.34 \pm 0.04)$, serum iron $(85.53 \pm 3.44)$, serum ferritin $(32.15 \pm 3.11)$ and transferrin saturation with iron $(22.43 \pm 1.62)$ were significantly reduced $(\mathrm{p}<0.01)$ in pregnant than non-pregnant women as presented in table 2 while total iron binding capacity $(422.43 \pm 19.60)$ and soluble transferrin receptor $(3.38 \pm 0.41)$ significantly $(\mathrm{p}<0.01)$ increased in pregnant than non-pregnant women. The percentages of pregnant women with abnormal level of indicators of iron status $(\mathrm{Hb}$, $\mathrm{MCV}, \mathrm{MCH}, \mathrm{SF}, \mathrm{TS}$, and STfR, ) is in shown in table 3. The table shows that the pregnant women recorded statistically significantly $(\mathrm{P}<0.05)$ higher number of abnormal level of indicators of iron status when compared to the non-pregnant women. The percentage of women with anaemia 14(20.0\%), iron deficiency 12 (17.9\%), iron deficiency anaemia $11(15.7 \%)$ and iron depletion $10(10.0 \%)$ were significantly higher in pregnant women when compared to non-pregnant women as shown in table 4. Pregnant women in their third trimesters had the highest prevalence of iron depletion, iron deficiency and iron deficiency anaemia while multgravidae recorded significantly higher prevalence of anaemia, iron deficiency and iron deficiency anaemia when compared to primigravidae, pregnant women in their second trimester also has the highest prevalence of anaemia (Table 5) When the pregnant women were grouped according to age (Table 5), those within the age range of 15-30 years had the highest prevalence of anaemia, iron deficiency, iron deficiency anaemia and iron depletion.

\section{Discussion}

Iron deficiency anaemia remains a widespread public health problem in most developing countries and even developed countries, a considerable number of women tend to have inadequate reserve to meet the requirement of pregnancy (Baynes et al.,1991). The prevalence of anaemia recorded in this study $(20.0 \%)$ is an indication that anaemia during pregnancy is still a problem in Nigeria especially among multigravidae. The prevalence and severity of anaemia recorded in this study differs from that recorded by Okafor at el $(61.1 \%)$, Ogbeide et al (20.7\%), Desalegn (41.9\%), Idowu et al. (76.8\%) and Usanga et al (79.1\%). This variance may be attributable to the fact that high percentage $(81.4 \%)$ of pregnant women that participated in this study were on iron supplementation and also to the differences in the geographical location of the study population which include Jimma Town in Ethiopia, Abeokuta Nigeria, Benin Nigeria and Ibadan Nigeria. The peak of anaemia and iron deficiency recorded in this study $\left(2^{\text {nd }}\right.$ trimester) coincides with the period when haemodilution is at its peak. This may have contributed to the high prevalence recorded in the $2^{\text {nd }}$ trimester, indicating that anaemia is further aggravated by haemodilution in pregnancy. However, this result is at variance with the report of WHO (1994) in which anaemia is said to be significantly higher in the $3^{\text {rd }}$ trimester of pregnancy than the first two trimesters. World Health Organization (WHO) data show that iron deficiency anaemia in pregnancy is a significant problem throughout the world with a prevalence ranging from an average of $14 \%$ of pregnant women in industrialized countries to an average of $56 \%$ in developing countries (WHO, 1994). The prevalence of iron 
deficiency $(17.90 \%)$, iron deficiency anaemia $(15.70 \%)$ and Iron depletion $(20.00 \%)$ recorded in this study are lower than that given by WHO (1994) for developing countries. This reduction in the prevalence of iron deficiency anaemia may be due to increased awareness of the need for iron supplementation during pregnancy as evidenced by the number of pregnant women that were on iron supplementation in this study and it can also be attributed to free antenatal policy that is currently practiced by the government of Cross River State, Nigeria which encourages women to register early for their antenatal. There is a great variation in the prevalence of iron deficiency anaemia reported by different authors Elzahrani, 2012 (22.6\%), Mahfouz et al, 1994 (31.9\%).

These differences could be explained by the strong association between the epidemiological variables. In comparison to another study carried out in south India (Mahfouz, et al, 1994), the prevalence of iron deficiency anaemia $(\mathrm{Hb}$ less than $11 \mathrm{~g} / \mathrm{dl}$ and serum ferritin less than $12 \mathrm{ug} / \mathrm{l})$ was found to highest among pregnant women in their second trimester while in our study the highest prevalence of iron deficiency anaemia was among the third trimesters, the difference in the findings may be due to differences in age groups or parity in the study groups. In the current study, it was found that anaemia, iron deficiency anaemia and iron depletion were significantly higher among the lower age group. In the Dugdale (2006) study, hemoglobin levels were negatively correlated significantly with increasing age. This may be due to cumulative obstetric conditions and maternal exhaustions, Women frequently enter pregnancy with insufficient nutrient stores, and thus the increased demand associated with pregnancy and later with lactation is reported to cause anaemia (Singh et al.,1998). Other studies support our association of high parity with iron deficiency(Zimmermann and Hurrel, 2007,Hindmarsh et al, 2000). Parity in particular appears to be associated, although not exclusively, with iron deficiency in studies carried out in developing countries (Agarwal et al 2006, Gibson et al,2008 ). It may be particularly important to inform multiparous women in developing countries, such as Nigeria, of the importance of adequate iron intake during pregnancy.

The salient feature of our study is a statistically significant decrease in $\mathrm{Hb}$, serum ferritin level, serumiron level, transferrin saturation with iron and a significant increase in total iron binding capacity (TIBC) and soluble transferrin receptor in pregnant women compared to non pregnant women. During pregnancy $\mathrm{Hb}$ level in woman is naturally lower than when she is not pregnant. This is because the plasma increases by about $50 \%$ during pregnancy (peaking at about 32 weeks) (Baynes et al., 1994). The increased plasma dilute the red cells, making their level drop. Serum ferritin usually falls markedly between 12 and 25 weeks of gestation, probably as a result of iron utilisation for expansion of the maternal red blood cell mass ( Hytten, 1985; Letsky, 1998).

Transferrin receptor is a disulphide-linked transmembrane glycoprotein that plays an essential role in cellular iron uptake, especially in bone marrow (Aiguo et al., 2002). Although it is a cell membrane protein, small quantities circulate in blood and are called soluble transferrin receptor (STfR) (Baynes et al., 1991).

Blood concentrations are increased several fold in subjects with iron deficiency, whereas they remain within the normal range in those with iron overload and anaemia of chronic disease. Serum STfR concentration is not affected by pregnancy unless the subject is also iron deficient (Åkesson et al,. 1998). Unlike serum ferritin, STfR is not affected by infection and inflammation and it may distinguish anaemia due to chronic disease from that due to iron deficiency (Ferguson et al., 1992; Carriaga et al.,1991). In this study, STfR was significantly increased in the pregnant women $(2.10 \pm 0.51)$ when compared to the non-pregnant women $(1.20 \pm 0.12)$. The significant $(\mathrm{P}<0.01)$ rise in STfR during pregnancy may be a combined result of reduced erythropoiesis in the first trimester along with an increase in erythropoiesis in the later stages of pregnancy and a concurrent development of tissue iron deficiency (Akesson et al., 1998). Our results corroborate with those of previous reports (Skikne et al., 1990, Ferguson et al., 1992) that STfR concentrations are higher in patients with iron deficiency.

In conclusion, the present study showed that the prevalence of iron deficiency and iron deficiency anaemia among pregnant women in Calabar were $17.6 \%$ and $15.7 \%$. Iron and folic acid supplementation during pregnancy seems to reduce the occurrence of iron deficiency and iron deficiency anaemia.

\begin{tabular}{lcl} 
Table 1 & Demographic characteristics of the study groups \\
\hline $\begin{array}{l}\text { Variables } \\
\text { Age }\end{array}$ & Pregnant women $(70)$ & $\begin{array}{l}\text { Number of } \\
\text { Non Pregnant women } \\
(50) 29\end{array}$ \\
27 & & $19(38.00 \%)$ \\
\hline Occupation & & $31(62.00 \%)$ \\
House wife & $38(54.29 \%)^{*}$ & $7(14.00 \%)$ \\
Others & $32(45.71 \%)^{*}$ & $15(30.00 \%)$ \\
Level & Education & $28(56.00 \%)$ \\
of & $5(7.10 \%)^{*}$ & - \\
Primary & $23(32.90 \%)^{*}$ & \\
Secondary & $42(60.00 \%)$ & \\
University & & \\
Number & $57(81.40 \%)$ & \\
taking & & \\
Haematenic & & \\
s & & \\
\hline
\end{tabular}


*means significantly different when compared to corresponding non-pregnant women value $(\mathrm{P}<0.05)$

Table 2 Haematological and biochemical parameters of pregnant and non-pregnant Women in Calabar

\begin{tabular}{lll}
\hline Parameters & $\begin{array}{l}\text { Non-pregnant women } \\
(\mathrm{n}=50)\end{array}$ & pregnant women $(\mathrm{n}=70)$ \\
\hline $\mathrm{Hb}(\mathrm{g} / \mathrm{dl})$ & $12.32 \pm 0.20$ & $11.86 \pm 0.13^{*}$ \\
$\mathrm{Hct}(1 / \mathrm{l})$ & $0.37 \pm 0.07$ & $0.36 \pm 0.04^{*}$ \\
MCV $(\mathrm{fl})$ & $80.94 \pm 1.40$ & $80.36 \pm 0.75$ \\
MCHC $(\mathrm{g} / \mathrm{dl})$ & $32.96 \pm 0.54$ & $33.13 \pm 0.12$ \\
MCH $(\mathrm{pg})$ & $27.11 \pm 0.54$ & $26.72 \pm 0.30$ \\
RBC $(\mathrm{g} / \mathrm{l})$ & $4.51 \pm 0.11$ & $4.46 \pm 0.04$ \\
SI $(\mathrm{ug} / \mathrm{dl})$ & $106.46 \pm 7.68$ & $76.52 \pm 4.60^{* *}$ \\
SF $(\mathrm{ng} / \mathrm{ml})$ & $54.64 \pm 7.76$ & $30.43 \pm 4.49^{* *}$ \\
TIBC $(\mathrm{ug} / \mathrm{dl})$ & $355.3 \pm 11.14$ & $392.24 \pm 37.59^{*}$ \\
TS $(\%)$ & $29.66 \pm 2.0$ & $21.33 \pm 1.41^{* *}$ \\
STfR $(\mathrm{ug} / \mathrm{ml})$ & $1.39 \pm 0.12$ & $2.10 \pm 0.51^{* *}$ \\
\hline
\end{tabular}

Key: Mean \pm SEM

**means significantly different when compared to corresponding non-pregnant women values $(\mathrm{P}<0.01)$

* means significantly different when compared to corresponding non-pregnant women values $(\mathrm{P}<0.05$

Table 3 Pregnant women with abnormal level of indicators of iron status in Calabar

\begin{tabular}{llll}
\hline Indicators of iron status & Abnormal range & Non-pregnant women $(\mathrm{n}=50)$ & $\begin{array}{l}\text { Calabar pregnant women } \\
(\mathrm{N}=70)\end{array}$ \\
\hline $\mathrm{Hb}(\mathrm{g} / \mathrm{dl})$ & $<12 \mathrm{~g} / \mathrm{dl}$ & $8(16 \%)$ & $14(20.00 \%)^{*}$ \\
$\mathrm{Hb}(\mathrm{g} / \mathrm{dl})$ & $<11 \mathrm{~g} / \mathrm{dl}$ & & $17(24.28)^{*}$ \\
$\mathrm{MCV}(\mathrm{fl})$ & $<78 \mathrm{fl}$ & $5(10.00 \%)$ & $24(34.20 \%)^{*}$ \\
$\mathrm{MCH}(\mathrm{pg})$ & $<26 \mathrm{pg}$ & $7(14.00 \%)$ & $14(20.00 \%)^{*}$ \\
$\mathrm{SF}(\mathrm{ng} / \mathrm{ml})$ & $<12 \mathrm{ng} / \mathrm{ml}$ & $5(10.00 \%)$ & $16(22.80 \%)^{*}$ \\
$\mathrm{TS}(\%)$ & $<15 \%$ & $1(2.00 \%)$ & $7(17.90 \%)^{*}$ \\
$\mathrm{STfR}(\mathrm{ug} / \mathrm{ml})$ & $>2.4 \mathrm{ug} / \mathrm{ml}$ & $1(2.00 \%)$ & \\
\hline
\end{tabular}

*These values are significantly different from the corresponding non-pregnant women values $(\mathrm{P}<0.05)$

Table 4 Prevalence of anaemia, iron deficiency, iron deficiency anaemia and iron depletion among pregnant and non-pregnant women in Calabar

\begin{tabular}{|l|l|l|}
\hline & $\begin{array}{l}\text { Non-pregnant women } \\
(\mathrm{N}=50)\end{array}$ & $\begin{array}{l}\text { Pregnant women } \\
(\mathrm{N}=70)\end{array}$ \\
\hline Anaemia & $8(16.0 \%)$ & $14(20.0 \%)^{*}$ \\
\hline Iron deficiency & $2(4.0 \%)$ & $12(17.9 \%)^{*}$ \\
\hline Iron deficiency anaemia & $2(4.0 \%)$ & $11(15.7 \%)^{*}$ \\
\hline Iron depletion & $5(10.0 \%)$ & $14(20.0 \%)^{*}$ \\
\hline
\end{tabular}

Iron depletion is defined as serum ferritin $<12 \mathrm{ng} / \mathrm{ml}$; iron deficiency is defined as soluble transferrin receptor $>2.4 \mathrm{ug} / \mathrm{ml}$; anaemia is defined as $\mathrm{Hb}<11 \mathrm{~g} / \mathrm{dl}$ in pregnant women and $\mathrm{Hb}<12 \mathrm{~g} / \mathrm{dl}$ in non pregnant women; iron deficiency anaemia is defined as soluble transferrin receptor $>2.4 \mathrm{ug} / \mathrm{ml}$ and $\mathrm{Hb}<11 \mathrm{~g} / \mathrm{dl}$ (Leng et al.,2004)

*These values are significantly different from the corresponding non-pregnant women values $(\mathrm{P}<0.05)$

Table 5 Classification Of Iron Status Of Pregnant Women According To Trimester, Age And Gravidity in Calabar

\begin{tabular}{lllll}
\hline & Anaemia & Iron Deficiency & $\begin{array}{l}\text { Iron Deficiency } \\
\text { Anaemia }\end{array}$ & $\begin{array}{l}\text { Iron } \\
\text { Depletion }\end{array}$ \\
& & & & $2(13.33 \%)$ \\
1st Trimester(n=15) & $1(6.67 \%)$ & $2(13.33 \%)$ & $2(13.33 \%)$ & $5(20.00 \%)$ \\
2ndTrimester(n=24) & $7(29.17 \%)^{*}$ & $3(12.50 \%)$ & $3(12.50 \%)$ & $7(23.33 \%)^{*}$ \\
3rdTrimester(n=30) & $6(20.00 \%)$ & $7(23.33 \%)^{*}$ & $6(20.00 \%)^{*}$ & $6(20.70 \%)$ \\
Primigravidae(n29) & $3(10.30 \%)$ & $4(13.80 \%)$ & $4(13.80 \%)$ & $8(19.50 \%)$ \\
Multigravidae(n=41) & $11(26.80 \%) \#$ & $8(21.70 \%) \#$ & $7(17.10 \%) \#$ & $14(26.40 \%)^{* *}$ \\
15-30years(n=53) & $12(22.60 \%)^{* *}$ & $10(18.90 \%)^{* *}$ & $10(18.90 \%)^{* *}$ & 0 \\
31-35years(n=17) & $2(11.80 \%)$ & $2(11.80 \%)$ & $1(5.90 \%)$ & 0 \\
\hline
\end{tabular}

*These values are significantly higher when compared to other trimesters $(\mathrm{P}<0.05)$

\#These values are significantly higher when compared to the other gravidae $(\mathrm{P}<0.05)$

$* *$ These values are significantly higher when compared to the other age group $(\mathrm{P}<0.05)$ 


\section{References}

[1]. Alhossain, A. \& Amanda, E. D. (2012). Iron Deficiency Anaemia in Pregnancy and Postpartum: Pathophysiology and Effect of Oral versus Intravenous Iron Therapy. Journal of Pregnancy, 2012, 1155-1165

[2]. Roskams, A. J. \& Connors, J. R. (1994). Iron transferring and ferritin in the rat brain during development and aging. Journal of Neurochemistry, 63(2), 709-716.

[3]. Finch, C. \& Huebers, H. (1996). Perspective in iron metabolism. New England Journal of Medicine 306,1520 -1528.

[4]. Bothwell, T. H. and Charlton, R. W. (1997). A general approach of iron deficiency and iron overload in the population at large. Seminars in Haematology, 19, 54.

[5]. Debenoist, B., Mclean E., Egli I. \& Cogswell M. (2008). Worldwide prevalence of anaemia 1993-2005, WHO Global Database on Anemia. Geneva: World Health Organization, 21.

[6]. Taylor, P. G. (1995). Iron bio-availability from diets consumed by different socio-economic strata of the Venezuelan population. Joural of Nutrition, 25, 1860-1868.

[7]. Baynes, R. D., Shih, Y. J. \& Cook, J. D. (1991). Production of soluble transferrin receptor by K563 erythroleukemia cells. British Journal of Haematology, 78, 450-455

[8]. Okafor, I. M., Akpan, P. A., Usanga, E. A. (2012). Prevalence and Types of Anaemia in Malaria Infected Pregnant Women Attending Antenatal Clinic in University of Calabar Teaching Hospital, Calabar, Nigeria. Journal of Natural Sciences Research, 2(7), 73-78

[9]. Ogbeide, O., Wagbatsoma, V. \& Orhue, A. (1994). Anaemia in Pregnancy. East African Medical Journal, 71(110), 671-673.

[10]. Desalegn, S. (1993). Prevalence of anemia in pregnancy in Jimma town, South-western Ethiopia. Ethiopian Medical Journal, 31, 251-258.

[11]. Idowu, O. A., Mafiana, C. F., Dapo, S. (2005). Anaemia in pregnancy: a survey of pregnant women in Abeokuta, Nigeria. African Health Science, 5(4), 295-9.

[12]. Usanga, E. A., (1990). Iron store of Nigerian Blood donors as assessed by serum frritin concentration. Central African Medical Journal, 36, 170-173.

[13]. World Health Organization (1994). Prevention and Management of Severe Anaemia in Pregnancy: report of a technical working group. Geneva: WHL/FHE/MSM/93.3.

[14]. Elzahrani, S. S. (2012). Prevalence of Iron Deficiency Anemia among Pregnant Women AttendingAntenatal Clinics at Al-Hada Hospital Canadian Journal on Medicine, 3(1), 10-14.

[15]. Mahfouz, A. A., El-Said, M. M., Alakija, W., Badawi, I. A. \& Al-Erian R. A. (1994) " Anemia Among Pregnant Women in the Asir Region, Saudia Arabia". Southeast Asian Journal of Tropical Medicine and Public Health, 25(1), 84-7

[16]. Dugdale, A. E., (2006). Predicting iron and folate deficiency anaemias from standard blood testing: the mechanism and implications for clinical medicine and public health in developing countries. Theoritical Biology and Medical Modelling, 3, 34.

[17]. Singh, K., Fong, Y. F. \& Arulkumaran, S.(1998). "Anemia in pregnancy a Cross Sectional Study in Singapore" European Journal of Clinical Nutrition, 52(1), 65-70.

[18]. Zimmermann, M. B. \& Hurrell, R. F. (2007) Nutritional iron deficiency. Lancet, 370, 511-520.

[19]. Hindmarsh, P. C., Geary, M. P., Rodeck, C. H., Jackson, M. R. \&Kingdom, J. C. (2000). Effect of early maternal iron stores on placental weight and structure. Lancet, 356, 719-723.

[20]. Agarwal, K. N, Agarwal, D. K., \& Sharma, A. (2006). Prevalence of anaemia in pregnant and lactating women in India. Indian Journal of Medical Research, 124, 173-184.

[21]. Gibson, R. S., Abebe, Y., Stabler, S., Allen, R. H., Westcott, J. E., Stoecker, B. J., Krebs, N. F. \& Hambidge, K. M. (2008) Zinc, gravida, infection, and iron, but not vitamin B-12 or folate status, predict hemoglobin during pregnancy in Southern Ethiopia. Journal of Nutrition 138, 581-586.

[22]. Baynes RD, Skikne B. (1994). Iron absorption. In: Brock, J.H., Halliday, J. W. Piparrd, M. J. and Powell, L.W. (eds). Iron metabolism in Health and disease. London, UK: WB Saunders; p. 151-87.

[23]. Hytten F. (1985). Blood volume changes in normal pregnancy. In: Letsky EA. (Ed). Hematological Disorders in pregnancy. London: WB Saunders; 1985. p. 601-12.

[24]. Letsky EA. (1998). The Hematological system. In: Broughton PF, Chamberlain GVP. (Eds). Clinical Physiology in Obstetric 3rd ed Oxford: Blackwell; p. 71-110.

[25]. Aiguo, M., Xuecun, C., Mingci, Z., Yu, W., Rongxian, X. \& Juesheng, L. (2002). Iron status and dietary intake of Chinese pregnant women with anaemia in the third trimester. Asia Pacific Journal of Clinical Nutrition, 11(3), 171-175.

[26]. Akesson, A., Bjellerup, P., Berglund, M., Bremme, K. \& Vahter, M. (1998) . Serum transferrin receptor: a specific marker of iron deficiency in pregnancy American Journal of Clinical Nutrition, 68, 1241-6.

[27]. Ferguson, B. J., Skikne, B. S., Simpson, K. M., Baynes, R. D. \& Cook, J. D. (1992). Serum transferrin receptor distinguishes the anemia of chronic disease from iron deficiency anemia. Journal of Laboratory and Clinical Medicine, 19, 385-390.

[28]. Carriaga, M. T., Skikne, B. S., Finley, B. S., Cutler, B. \& Cook, J. D. (1991). Serum transferrin receptor for the detection of iron deficiency in pregnancy. American Journal of Clinical Nutrition, 54, 1077-1081.

[29]. Skikne., B. S., Flowers, C. H, \& Cook, J. D., (1990). Serum transferrin receptor: a quantitative measure of tissue iron deficiency. Blood, 75, 1870-1890. 